\title{
SPINE INJURIES DURING THE SIX-DAY WAR
}

\author{
By E. AdLeR, M.D. \\ Department of Physical Medicine and Rehabilitation, Hebrew University \\ Hadassah University Hospital, Ferusalem
}

In this paper we shall present data about the clinical course, final outcome and rehabilitation of the cases of nine soldiers (eight paraplegics and one quadriplegic), wounded in their spines during the six-day war in June 1967. They were hospitalised in our department for three months up to more than one year (after having received initial treatment in the departments of neurosurgery, orthopedics, general surgery, chest surgery, or in two or three of these together). These soldiers constitute more then 60 per cent. of injured combatants of this kind in this war.

In the following Tables (I to VI), site of injury, initial symptomatology, complications, course of treatment and the features of final rehabilitation shall be

TABLE I

\begin{tabular}{|c|c|c|c|}
\hline Name & Cause & Initial findings & $\mathrm{X}$-ray \\
\hline M.M. & Shrapnel & $\begin{array}{l}\text { Paraplegia (cauda equina); } \\
\text { sensory level L2 }\end{array}$ & Fracture of lamina $\mathrm{L}_{3}$ \\
\hline A.D. & Bullet & $\begin{array}{l}\text { Complete tetraplegia sen- } \\
\text { sory level THI, hypo- } \\
\text { tension. Bradycardia. } \\
\text { Respiratory arrest }\end{array}$ & Fracture of lamina $\mathrm{C}_{5}$ \\
\hline D.P. & Shrapnel & $\begin{array}{l}\text { Paraplegia, sensory level } \\
\mathrm{TH}_{4} \text { shock }\end{array}$ & $\begin{array}{l}\text { Fracture of lamina } \mathrm{TH}_{4}, \\
\mathrm{TH}_{5}\end{array}$ \\
\hline M.K. & Shrapnel & $\begin{array}{l}\text { Paraplegia, sensory level } \\
\text { THI I }\end{array}$ & $\begin{array}{l}\text { Fragment between THI I } \\
\text { and THI2 }\end{array}$ \\
\hline B.G. & Shrapnel & $\begin{array}{l}\text { Paraplegia (cauda equina), } \\
\text { sensory level L5 }\end{array}$ & $\begin{array}{l}\text { Fracture \& ant. dislocation } \\
\quad \text { of } \mathrm{L}_{5}\end{array}$ \\
\hline Y.S. & Shrapnel & $\begin{array}{l}\text { R. monoparesis. Hyper- } \\
\text { algesia R. arm }\end{array}$ & Fracture of $C_{5}, 6$ \\
\hline L.A. & Mine & $\begin{array}{l}\text { R. hemiplegia. L. Hemi- } \\
\text { anesthesia Brown- } \\
\text { Séquard's syndrome, } \\
\text { shock }\end{array}$ & Fracture of $\mathrm{C}_{5}, 6$ \\
\hline A.H. & Car accident & $\begin{array}{l}\text { Paraplegia (cauda equina), } \\
\text { sensory level } S_{I}\end{array}$ & Fracture-dislocation $\mathrm{LI}_{\mathrm{I}}$ \\
\hline M.I. & Car accident & Paraplegia, sensory level $D_{5}$ & Fracture-dislocation $\mathrm{D}_{7}$ \\
\hline
\end{tabular}


illustrated. It goes without saying that only very well organised teamwork on the part of the whole staff, co-operation with the extremely helpful authorities of the defence ministry, intensive aid on behalf of the colleagues of many other departments, particularly those of urology and psychiatry; furthermore, a co-ordinated psychological approach on behalf of each member of the team, physiotherapists, occupational therapists, nurses and social workers included, with much time devoted to the individual problems of each patient-and last but not least-a very active and constructive co-operation of the patients themselves, almost without exception, have rendered possible some remarkable achievements in rehabilitation. It should be stressed that we were able to give every intensive individual treatment in every regard because of the relatively small number of these cases and because of the emotional attitude of the whole staff toward this group of soldiers. We do not intend to describe the routine measures and treatment in these cases centred on physical therapy, occupational therapy, psychotechnical tests, prevocational training, evaluation and preparation of appropriate housing accommodations, etc.

Table I shows the initial findings.

Table II describes the relatively great amount of additional injuries and their

TABLE II

\begin{tabular}{|c|c|c|}
\hline Name & Additional injuries & Surgery \\
\hline M.M. & None & Laminectomy of $\mathrm{L}_{2}-\mathrm{L}_{3}$ \\
\hline A.D. & Bullet through esophagus & $\begin{array}{l}\text { Laminectomy of } \mathrm{C}_{5} \text {-THI. } \\
\text { Tracheostomy. Feeding } \\
\text { gastrostomy }\end{array}$ \\
\hline D.P. & $\begin{array}{l}\text { Haemothorax. Intestinal lacera- } \\
\text { tions. Fractures of L. tibia \& } \\
\text { fibula, R. ankle, R. olecranon. } \\
\text { L. ulnar paresis }\end{array}$ & $\begin{array}{l}\text { Thoracotomy. Laparatomy. } \\
\text { Open reduction of fractures }\end{array}$ \\
\hline M.K. & $\begin{array}{l}\text { Haemothorax. Intestinal lacera- } \\
\text { ations. Fractures of L. radius } \\
\text { \& ulna }\end{array}$ & $\begin{array}{l}\text { Thoracotomy. Laminectomy of } \\
\text { THio-I2. Laparatomy. Re- } \\
\text { exploration of wound }\end{array}$ \\
\hline B.G. & None & $\begin{array}{l}\text { Laminectomy of } \mathrm{L}_{3}-5 \cdot \mathrm{Re}- \\
\text { exploration of wound }\end{array}$ \\
\hline Y.S. & None & None \\
\hline L.A. & $\begin{array}{l}\text { Tear of R. int. jugular vein. } \\
\text { traumatic amputation } \mathrm{R} \text {. arm } \\
\text { below elbow. Haemothorax }\end{array}$ & $\begin{array}{l}\text { Tracheostomy. Suture of jugular } \\
\text { vein. Thoracotomy. Surgical } \\
\text { re-amputation }\end{array}$ \\
\hline A.H. & None & $\begin{array}{l}\text { Laminectomy of LI. Plate } \\
\text { fixation }\end{array}$ \\
\hline M.I. & None & Open reduction. Plate fixation \\
\hline
\end{tabular}


treatment. In more than half of the cases, laminectomy has been performed; it remains open for discussion whether this was necessary in each case.

Table III shows the bladder and bowel condition and sexual function. Only in two cases intermittent catheterisation has been applied almost from the start, due to the devoted effort of my junior assistant, Dr. R. Rozin. This method has proved its superiority over all other methods not only in these two cases, but we have at this very moment in our department, three other cases having been injured by accidents, which are being successfully treated in this same way. As you may see from this table, five of the victims have normal bladder-function, two achieved an automatic bladder and two (one of them the quadriplegic) a partial automatic bladder. The bowel-motions are regulated in all cases rather satisfactorily. As for the sexual function, only in three cases normal function exists; in all other cases either erection was present or even this did not happen.

TABLE III

\begin{tabular}{|c|c|c|c|}
\hline Name & Bladder & Bowel & Sexual function \\
\hline M.M. & Foley catheter for 26 days & Normal & Normal \\
\hline A.D. & $\begin{array}{l}\text { Foley catheter for } 165 \text { days. Reflex } \\
\text { micturition \& intermittent cath- } \\
\text { eterisation (partial automatic) }\end{array}$ & $\begin{array}{l}\text { Regulated by } \\
\text { laxatives }\end{array}$ & Erection present \\
\hline D.P. & $\begin{array}{l}\text { Foley catheter for Ioo days. Reflex } \\
\text { micturition (automatic) }\end{array}$ & Laxatives & No erection \\
\hline M.K. & $\begin{array}{l}\text { Foley catheter for } 96 \text { days. Reflex } \\
\text { micturition (partial automatic) }\end{array}$ & Laxatives & No erection \\
\hline B.G. & $\begin{array}{l}\text { Foley catheter for } 37 \text { days. Normal } \\
\text { micturition }\end{array}$ & $\begin{array}{l}\text { Regulated by } \\
\text { laxatives } \\
\text { (no sensation) }\end{array}$ & Normal \\
\hline Y.S. & Normal & Normal & Normal \\
\hline L.A. & $\begin{array}{l}\text { Foley catheter for } 50 \text { days. Normal } \\
\text { micturition }\end{array}$ & Normal & Unknown \\
\hline A.H. & $\begin{array}{l}\text { Foley catheter for I } 8 \text { days. Volun- } \\
\text { tary micturition (no sensation) }\end{array}$ & $\begin{array}{l}\text { Regulated by } \\
\text { laxatives } \\
\text { (no sensation) }\end{array}$ & Impotence \\
\hline M.I. & $\begin{array}{l}\text { Foley catheter for I } 6 \text { days. Inter- } \\
\text { mittent catheterisation (automatic) }\end{array}$ & $\begin{array}{l}\text { Regulated by } \\
\text { laxatives }\end{array}$ & Erection present \\
\hline
\end{tabular}


Table IV deals with complications. Attention is drawn to cases No. 2 and No. 4. In the first we had the oesophageal fistula and in the second a real psychotic behaviour and even today there exists a chronic osteomyelitis.

Table $\mathrm{V}$ shows the final clinical findings and final functional conditions, except for case No. 7 whose fate is unknown to us. Only the tetraplegic is entirely dependent.

Table VI shows the vocational rehabilitation. It should be stressed that the quadriplegic, thanks to the attitude of the University and the Professor of Mathematics, is able to attend to these studies; the 8th case has, in the meantime, returned to work with his father in his factories abroad; and the 9th case has started with studies at the University.

In other words, all the cases are vocationally rehabilitated.

Summarising, we may conclude:

I. A short report is given of nine cases of spine lesions in soldiers wounded during the six-day war, hospitalised in the Hadassah University Hospital in Jerusalem and treated in the Department of Physical Medicine and Rehabilitation.

TABLE IV

\begin{tabular}{|c|c|c|}
\hline Name & Complications & Treatment \\
\hline M.M. & Pains (causalgiform?) & Phenergan, Optalgin \\
\hline A.D. & $\begin{array}{l}\text { Oesophageal fistula (infected) } \\
\text { pneumonia, urinary infection, } \\
\text { calcifications around R. hip } \\
\text { joint }\end{array}$ & $\begin{array}{l}\text { Antibiotics, mandelamine, } \\
\text { Gantrisin }\end{array}$ \\
\hline D.P. & Pneumonia & $\begin{array}{l}\text { Antibiotics, Mandelamine, } \\
\text { Gantrisin }\end{array}$ \\
\hline M.K. & $\begin{array}{l}\text { Acute psychosis. Urinary infec- } \\
\text { tion. Osteomyelitis of THI I-I2 } \\
\text { with fistula }\end{array}$ & $\begin{array}{l}\text { Antibiotics, chlorpromazine, } \\
\text { Mandelamine, Gantrisin. }\end{array}$ \\
\hline B.G. & $\begin{array}{l}\text { Pains (causalgiform?). Osteo- } \\
\text { myelitis of L5 with fistula }\end{array}$ & $\begin{array}{l}\text { Phenergan, Optalgin, Antibiotics, } \\
\text { plaster jacket for } 5 \mathrm{mths} \text {. }\end{array}$ \\
\hline Y.S. & None & None \\
\hline L.A. & $\begin{array}{l}\text { Cardiac standstill, cerebral anoxia, } \\
\text { loss of memory }\end{array}$ & $\begin{array}{l}\text { Resuscitation, antibiotics. Crutch- } \\
\text { field tongs }\end{array}$ \\
\hline A.H. & Urinary infection & Antibiotics \\
\hline M.I. & Pleural effusion & $\begin{array}{l}\text { Pleural puncture, antibiotics. } \\
\text { Mandelamine, Gantrisin }\end{array}$ \\
\hline
\end{tabular}


2. Initial symptomatology and treatment, complications, their handling, sphincter-function, vocational program and rehabilitation are outlined in tables.

3. Special emphasis is laid on the use of intermittent catheterisation as a procedure of choice for the neurogenic bladder.

4. Only a few complications occurred and they did not seriously aggravate the outlook for rehabilitation. This can be explained by the limited number of patients who were able to enjoy the utmost individual treatment by the combined effort of the staff and all other factors concerned.

5. Early vocational evaluation and its implementation during hospitalisation has added to the final success in the work of these cases.

6. Eight of the nine severely injured soldiers-the fate of the ninth is unknown to us-are either employed in useful work or are successfully studying toward the goal of gainful occupation.

\section{TABLE V}

\begin{tabular}{|c|c|c|}
\hline Name & Present clinical findings & Present functional status \\
\hline M.M. & $\begin{array}{l}\text { Flaccid paralysis of } \mathrm{L} . \text { leg. } \\
\text { paresis of } \mathrm{R} \text {. leg. Anaesthesia } \\
\text { only in L5 segment }\end{array}$ & $\begin{array}{l}\text { Walks freely with two long-leg } \\
\text { braces. Independent }\end{array}$ \\
\hline A.D. & $\begin{array}{l}\text { Partial return of power: deltoid } \\
\text { biceps, triceps bil., pect. maj. R. } \\
\text { sensitivity no change. Mild } \\
\text { spasticity }\end{array}$ & $\begin{array}{l}\text { Sitting in wheelchair. Training } \\
\text { with ballbearing feeder; typing, } \\
\text { almost entirely dependent }\end{array}$ \\
\hline D.P. & Same as initial. Flaccid & $\begin{array}{l}\text { Swing-through gait with two long- } \\
\text { leg braces. Almost independent }\end{array}$ \\
\hline M.K. & Same as initial. Flaccid & $\begin{array}{l}\text { Swing-through gait with two long- } \\
\text { leg braces. Almost independent }\end{array}$ \\
\hline B.G. & $\begin{array}{l}\text { Paresis of both legs. Sensory level } \\
\text { R.-S2, L.-L5 }\end{array}$ & $\begin{array}{l}\text { Walks with two short-leg braces } \\
\& \text { crutches. Independent }{ }^{\star}\end{array}$ \\
\hline Y.S. & Muscle power almost normal & No limitations. Independent \\
\hline L.A. & $\begin{array}{l}\text { Some improvement of muscle } \\
\text { power }\end{array}$ & $\begin{array}{l}\text { Not known (transferred to another } \\
\text { hospital) }\end{array}$ \\
\hline A.H. & $\begin{array}{l}\text { Bilateral paresis of dorsiflexors, } \\
\text { saddle anaesthesia }\end{array}$ & $\begin{array}{l}\text { Walks freely with one cane. } \\
\text { Independent }\end{array}$ \\
\hline M.I. & Same as initial & $\begin{array}{l}\text { Swing-through gait with two long } \\
\text { leg braces. Almost independent }\end{array}$ \\
\hline
\end{tabular}

* Execution of rehabilitation procedures difficult due to additional injuries and complications. 
TABLE VI

\begin{tabular}{|c|c|c|c|c|}
\hline Name & Age ! & Disability & Previous occupation & Present vocational program \\
\hline M.M. & 24 & Cauda equina & Farmer (Kibbutz) & $\begin{array}{l}\text { Learned to drive-works } \\
\text { in factory (Kibbutz) }\end{array}$ \\
\hline A.D. & 22 & Tetraplegia & $\begin{array}{l}\text { Medical student } \\
\text { (freshman) }\end{array}$ & $\begin{array}{l}\text { Learning English, study- } \\
\text { ing Maths. University } \\
\text { - towards work with } \\
\text { computer }\end{array}$ \\
\hline D.P. & 20 & Paraplegia & $\begin{array}{l}\text { Electronic } \\
\text { technician }\end{array}$ & $\begin{array}{l}\text { Studying electronic } \\
\text { engineering }\end{array}$ \\
\hline M.K. & 20 & Paraplegia & Student of biology & Back at previous studies \\
\hline B.G. & 23 & Cauda equina & $\begin{array}{l}\text { Studied engineer- } \\
\text { ing }\end{array}$ & $\begin{array}{l}\text { Learned to drive, back at } \\
\text { previous studies }\end{array}$ \\
\hline Y.S. & 28 & Monoparesis & Farmer (Kibbutz) & Back at previous work \\
\hline L.A. & $2 \mathrm{I}$ & $\begin{array}{l}\text { Brown-Séquard } \\
\text { syndrome }\end{array}$ & $\begin{array}{l}\text { Soldier-Regular } \\
\text { army }\end{array}$ & Not known \\
\hline A.H. & 22 & Cauda equina & $\begin{array}{l}\text { Light industry- } \\
\text { volunteer }\end{array}$ & Studying Hebrew \\
\hline M.I. & $19 \frac{1}{2}$ & Paraplegia & $\begin{array}{l}\text { Soldier-Regular } \\
\text { army }\end{array}$ & Started driving lessons \\
\hline
\end{tabular}

\section{STABILISATION OF THE SPINE IN TRAUMATIC PARAPLEGIA}

By Alexander M. Katznelson, B.S., M.D.

Orthopedic Department Tel-Hashomer Hospital, and the Medical School of Tel Aviv University

IN traumatic paraplegia we have a condition wherein there is an acute damage to the spinal cord.

In man the spinal cord lies within a fluid bed surrounded by its membranes and is protected by the bony structure of the spine, which is formed anteriorly by the vertebral body, laterally by the pedicles, and the laminae form the posterior portion. This is not a solid tube, for to permit motion there are two sets of joints. The amphiarthrodial joints which are connected by intervening discs of fibro- 